\title{
Integrated Earth and Space Science Learning Model That Accommodate Multiple Intelligences to Improve The Mastery of Concept of Secondary School Students
}

\author{
Ainun Suciati \\ Students of Physics Education Study Program \\ Universitas Pendidikan Indonesia \\ Bandung, Indonesia \\ ainun.suciati@yahoo.com \\ Tatang Herman
}

\author{
Winny Liliawati \\ Physics Education Study Program \\ Universitas Pendidikan Indonesia \\ Bandung, Indonesia \\ winny.liliawati@gmail.com
}

\author{
Judhistira Aria Utama \\ Physics Education Study Program \\ Universitas Pendidikan Indonesia \\ Bandung, Indonesia \\ judhistira@yahoo.com
}

\begin{abstract}
The aim of the research was to determine the implementation of integrated learning model from students in 9 grades secondary school in Warungkiara, Sukabumi District. This learning model basically combine the various related matter in order to produce some theme that can support the student's intelligence. The instrument used on this research are identification tests of multiple intelligences, assessment of multiple intelligences activities (self and peer assessment) and test mastery of concept. The research showed integrated earth and space science learning model can facilitate student's intelligence and improve student's concept understanding of earth structure and disaster.
\end{abstract}

Keywords-integrated earth and space science learning model; multiple intelligences; concept mastery

\section{INTRODUCTION}

At the secondary school science subjects term is to study about the living being and it's life process, the matter and nature, the energy and it's concervation, and the earth and space. Earth and space science is integration and synthesis of physics, biology, chemistry, oceanography, meteorology, geophysics, geology, and astrophysics [1]. The meaning of this statement is earth and space have related with inter/intra disciplines to explain the natural phenomenon. For learning earth and space concept, it was needed several other related disciplines, it intended to make learning becomes meaningful, exhaustive and comprehensive/holistic. Based on results of the achievements of Mathematics and Science in TIMSS (Trend International Mathematics and Science Study) for secondary school students, on earth and space science Indonesia has four times participate in 1999, 2003, 2007 and 2011. The result showed Indonesia only obtain an average of 429 , it is smaller than the international average in amount of 491 [2]. This study proves that students still considered that the earth and space science was difficult. Actually earth and space science is very important because it learn about nature concept that related to global issues, such as phenomenon of the earth and space that would give big contribution to knowledge.

Meanwhile, based on results of the study through interview with some students and teachers in SMPN 26 Bandung, that obtained some students still less mastery about earthquake concept. Even though, the interview results with some students showed that the concept of earth and space is interesting because it discuss about the daily phenomenon that can be observed directly by students. But the student's interest wasn't followed with the understanding and concept mastery. There were multiple factors that caused less students understanding, one of the factors is the difference of each student's understanding concept, because basically students have different intelligences and abilities in understanding the concept. According to Gardner [3] every child does not have just one single intelligence, instead there have multiple abilities/intelligences. Another factor that caused the less students understanding is the teaching approach that used by teachers, most of teachers only focus on the linguistic and logical intelligence. Meanwhile according to Jasmine [4] learning need to be able to understand the ability of students personally, acknowledge its existence with all the capabilities that possesses, and appreciate the students' talent. Once the implementation of learning process only focus on one or two intelligences, this will lead inaccommodation of other several student's intelligences.

Based on these passages, we need an innovative learning that can address the different needs of student's intelligence and also for improving the understanding of student's concept. Integrated earth and space science learning model that accommodate multiple intelligences can be considered appropriate if being applied in learning the earth structure and disaster matter especially on earthquake concept, with not ignore the various of student's multiple intelligences. Integrated earth and space science learning model that 
accommodate multiple intelligences can associate related aspect of several subjects or disciplines, therefore this model intended to be able to help the students in understanding the concept of earthquake as holistic and meaningful. This research was expected to become an innovation in learning the concept which was considered suitable with this model. Thereby this research was expected to support the curriculum development in secondary school, such as in learning activities that have integrated matter with other disciplines.

\section{A. Multiple Intelligences}

Each child was born with the ability/intelligence, such as admiration, curiosity, spontaneity, vitality, and flexibility [5]. In line with this reasoning, Gardner [3] stated that every people has a lot of intelligences in varying levels since born. Gardner point out that there was eight type of intelligences in every people and some intelligences (one/more) become dominant. Gardner [3] explained that eight types of intelligences include, logical-mathematical intelligence, verbal-linguistic intelligence, musical intelligence, visual-spatial intelligence, kinesthetic intelligence, interpersonal intelligence, intrapersonal intelligence, and naturalistic intelligence. The multiple intelligences that suggested by Gardner is known as Multiple Intelligences Theory (MI Theory). Below is Gardner's explanation [3][4] about multiple intelligences.

\section{1) Logical-Mathematical Intelligence}

Logical-mathematical intelligence is about analyzing and solving the problems by using logic, critical thinking and abilities. A person who has this intelligence tend to involves numbers, various of patterns, counting, measurement of geometry, statistics, possibility, logic, graph and strategy games.

\section{2) Verbal-Lingustic Intelligence}

Verbal-linguistic intelligence is the ability of language as being sensitive to words and being good at learning of writing. A person who has this intelligence tend to involves like alphabet, sound, reading, writing, listening, speaking, discussing, making oral reports, and playing a crossword.

\section{3) Musical Intelligence}

Musical intelligence is the ability that involves to express musical forms, sensitive to any kind of music, rhythm/patterns, pitch. A person who has this intelligence involves being able to singing, whistling, creating music instruments/melody, and dancing.

\section{4) Visual-Spasial Intelligence}

Visual-spatial intelligence is the ability to identify spaces and thinking of visual images, such as sensitive of color, line and form. A person who has this intelligence involves being able to something related with film, video image/painting, demonstrating, model/prototype, painting, carving, map, and diagram.

\section{5) Kinestetic Intelligence}

Kinesthetic intelligence refers to the ability of using body to express ideas/feelings and use body in the process of problem solving. A person who has this intelligence tend to not being able to stand still, working with his hands and feet, attempting to touch the other people who were invited to speak, physical activities, demonstrating, dancing, sports, and body language.

\section{6) Interpersonal Intelligence}

Interpersonal intelligence is the ability to understand people and empathize with them, being able to work with others effectively and efficiently. A person who has this intelligence tend to involves group learning, group projects and group discussion, active in learning, responsible in organization, conflict resolution, social relations and empathy.

\section{7) Intrapersonal Intelligence}

Intrapersonal intelligence is the ability of self knowledge and understanding one's own feelings, thought, ambitions, worries, abilities, strength, and weakness. A person who has this intelligence tend to involves reflection, feeling, confident, analysis of self, independent, discipline, time management and future planning.

\section{8) Naturalist Intelligence}

Naturalist intelligence is ability to love and care of environment and other living creatures. A person who has this intelligence tend to involves to keep animals and plants, take care of environment, concerned about the disaster and the surrounding of environment.

\section{B. Concept Mastery}

The mastery of concept is the ability of students to understanding the meaning of theory sciencetificly and applying it on daily life [6]. Refers to that statement, concept mastery is the ability of students to understand and apply the matter/concept that has been learned on daily life. On learning process, the mastery of concept is very important, because it's not only to remember, but it's required to apply the matter that has been studied on daily life. Therefore it can make the learning become more meaningful. With the mastery of concept, student can improve their intelligence and also can solve the problem in their life. Concept mastery is obtained from the experience and learning process. Individual learner can be called having a mastery of concept if they were be able to explain the concept using their other own words without changing the meaning of the content.

The mastery of concept is the result of learning cognitive aspects that can be identified by doing concept mastery tests. Thought the test we intended to know the learning achievements of individual learners. The results of students learning may influence by the various factors, such as internal factors (themselves) and external factors (schools, family and community). According to Clark [7] revealed that the results of student learning at the schools $70 \%$ influenced by the ability of students and $30 \%$ influenced by the environment. Related to that statement, we're required motivation, perseverance, habits of learning, and learning approach that suitable to help the student's concept mastery. Integrated Earth and Space Science Learning Model that Accommodate Multiple Intelligences

According to Arends [8], selecting the learning model was influenced by the subjects matter and the ability of 
individual learners. There was various models that can be selected and used for learning in the classroom, one of them is the integrated learning. Integrated learning is a approach that combines various aspects from several related subjects in a theme in order to provide the meaningfull learning for students holisticly/comprehensively [8]. Integrated earth and space science learning model that accommodated multiple intelligences is a learning model that combine the various related matter in order to produce some theme that can support the student's intelligence. In line with Gardner's statement, this learning model can be considered appropriate if being applied in learning the earthquake concept, with not ignore the distinct of student's multiple intelligences. On other hand, this learning model can help the students to understanding the concept of earthquake as holisticly and meaningfully.

According to the theory of an integrated curriculum model by Forgaty [9], there were ten ways to integrate curriculum and there were five curriculums that are suitable to be applied on science, include connected, shared, webbed, threaded and integrated. According to Liliawati [10] curriculum threaded and webbed can be combined and used simultaneously in the implementation of learning in order to accommodate multiple intelligences and improve the mastery of student's concept. Webbed curriculum term is the concept of earth and space science that related with other disciplines in a theme. Threaded curriculum emphasizes to meta kurikulum that based on multiple intelligences. Threaded curriculum described with big circle that covers the webbed curriculum. The following Fig 1. shown the combined between webbed and threaded curriculum.

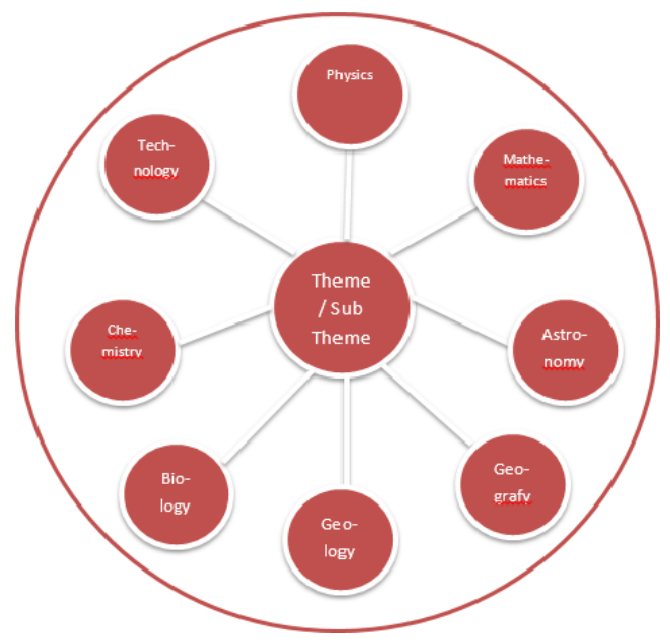

Fig. 2. The Combined of Threaded and Webbed Curriculum

\section{RESEARCH METHOD}

\section{A. Research Design}

The method which was used in this research is mixed method with concurrent embedded design. In this research, the quantitative method was used as a primary (the used of quantitative method is more) and qualitative method as a secondary (the used of qualitative is less).

\section{B. The population and Samples}

The participant in this research is 9 grade students (38 students) at SMPN 1 Warungkiara, Sukabumi District. The sample of this research are the students of IX A class. Purposive sampling was used in this research. Purposive sampling is a sampling that relies on judgement of the research when it comes to selecting data that are to be studied.

\section{Research instrument}

The instrument that used in this research consists of multiple intelligence questionnaire, test of concept mastery and observation sheet of multiple intelligences activity.

\section{1) Multiple Intelligences Questionnaire}

Multiple intelligences questionnaire consists of several statements which contain the scope of the multiple intelligences. The statements are adapted from adapted from talent test by Greg Gay and J Ivanco [11]. Questionnaire was used to identify the student's multiple intelligences.

\section{2) Concept Mastery Test}

The mastery of concept test contains the questions about the earth structure and disaster that have been studied in integrated earth and spaces science learning model. These tests was used to know about student's concept mastery.

\section{3) Observation Sheet of Multiple Intelligences} Activity

The assessment that used to observe student multiple intelligences activity consist of three assessment including self assessment, peer assessment, and observer assessment. This observation contains the related statements about multiple intelligences activity which aims to know the appeareance of students multiple intelligences activity.

\section{Data Analysis \\ 1) Multiple Intelligences Questionnaire}

The questionnaires consist of 24 statements that represents the students multiple intelligences. Each statement was assessed using likert scale with rating scale 0-4. While each multiple intelligences are in random formation. The students score is calculated from each intelligences vertically after answering the questionnaire. The biggest score from one of multiple intelligences is the dominant intelligences belong to students.

2) Observation Sheet of Multiple Intelligences Activity

The observation consists of self assessment, peer assessment and observer assessment. The aim of this assessment is to find out the appearance of multiple intelligences activity. There are five statements on every intelligences, with "yes" or "no" word, choose by students on every statement. The score have the range scale between $0-1$, score 1 for "yes" and score 0 for "no". The result from self assessment, peer assessments and observer assessments of multiple intelligences activities were being averaged out. For assessing the result of appearance of students multiple intelligences activities can be obtained by calculating the average of student's multiple intelligences activity, then devided by number of observer, and lastly the result times with $100 \%$. 


\section{3) Concept Mastery Test}

The data about student's concept mastery was obtained using $N$-gain, statistic, and descriptive. The $N$-gain was used to find out the improvement of students concept mastery on integrated earth and space science learning model that accommodated multiple intteligences. The equation Hake [12] to calculate $N$-gain as follow:

\section{TABLE I. N-GAIN INTERPRETATION}

\begin{tabular}{|c|c|}
\hline Gain & Interpretation \\
\hline $\mathrm{g} \leq 0,30$ & low \\
\hline $0,30<\mathrm{g} \leq 0,70$ & middle \\
\hline $0,70<\mathrm{g} \leq 1,00$ & high \\
\hline
\end{tabular}

\section{RESULTS AND DISCUSSION}

\section{A. Identification of Multiple Intelligences}

Identification of student's multiple intelligences was obtained from the results of multiple intelligences questionnaires againts 38 students before learning activities begin. This multiple intelligences questionnaires aim is to identify the student's dominant intelligence. It purpose is to help researchers for designing integrated earth and space science learning model that accommodate multiple intelligence. The result showed there are several students who only have one dominant intelligence and there are some students who have more than one dominant intelligences. The following Table II showed the number and percentage of the student's dominant multiple intelligences.

\section{TABLE II. NUMBER AND PERCENTAGE OF THE STUDENT'S} DOMINANT MUTIPLE INTELLIGENCES

\begin{tabular}{|c|c|c|}
\hline $\begin{array}{c}\text { Dominant Multiple } \\
\text { Intelligences }\end{array}$ & $\begin{array}{c}\text { Number of } \\
\text { Students }\end{array}$ & $\begin{array}{c}\text { Percentage } \\
(\%)\end{array}$ \\
\hline Naturalistic & 10 & 26 \\
\hline Logical-Mathematical & 5 & 13 \\
\hline Verbal-Linguistic & 3 & 8 \\
\hline Musical & 7 & 8 \\
\hline Visual-Spatial & 3 & 8 \\
\hline Kinesthetic & 3 & 32 \\
\hline Interpersonal & 12 & 47 \\
\hline Intrapersonal & 18 & \\
\hline
\end{tabular}

In Table II, the highest percentage of dominant multiple intelligences were intrapersonal and interpersonal intelligence. Intrapersonal intelligence get $47 \%$ students or belong to 18 students. Intrapersonal intelligence is the ability to understand ourselves. Secondary school students have reached the puberty, which is the physical, psychological, social, and intellectual began to develop, in other word the changes were occured on these aspects. Therefore students tend to process of self introduction or self understanding. In addition according to Jasmine [4], self understanding related with the feeling, confident, self analysis, self esteem, independent, discipline, time management and future planning. Based on that statements, it's proper that many students have intrapersonal intelligence as their dominant intelligence. Interpersonal intelligence get $32 \%$ or belong to 12 students. It made interpersonal intelligence as second highest of dominant intelligences. Interpersonal intelligence is the ability of social interaction, such as being able to work with other effectively and efficiently. Students with this intelligence will be easier to associate and communicate with other people [13].

The lowest of dominant intelligence of students were verbal-linguistic, visual-spatial, and kinesthetic intelligence. These intelligences only get $8 \%$ or belong to 3 students. Refers to the explanation of Jasmine and Gardner [2][3], there were several factors that make visual-spatial, verballinguistic, kinesthetic intelligence as the lowest of student's dominant intelligence. One of the factors lead to less accommodated of several student's intelligence in the implementation of learning. This was based on the results of unstructured interview with some teachers. The result was obtained during teaching and learning activity process, the teachers still considered it's difficult to develop the innovative learning. Even though the teacher has designed the learning with innovative methods such as using multimedia, experiment, and discussions activity, but during learning activity they still found some problems, such as less of sufficient multimedia projector supply, less of time experiments, and lack of student's ability on discussion. It enforced teacher to use conventional method which only focus on the linguistic and logical intelligence. This will lead to unaccomodated several student's intelligences, because learning process only focus on one or two intelligences. This points out that visual-spatial, verbal-linguistic, and kinesthetic intteligence owned by students become less or not accommodated. Hamzah [13] highlighted that the treatment could influence the development of student's intelligence. Refers to that explanation, it's proper if only some or few students that have the dominant intelligence on visual-spatial, verbal- linguistic and kinesthetic intelligence.

Dominant of naturalist intelligence get $26 \%$ or belong to 10 students. Naturalist intelligences is the ability to love and care for the environment. According to observation, the higher percentage of this intelligence was influenced by natural factors of their environment. Beautiful natural environment and good place, free of pollution, filled by the mountains, beach, and it sure can develop naturalistic intelligence. In addition the result showed the dominant intelligence of musical got $18 \%$ or belong to 7 students. It indicates that a lot of students have the ability to love activities which related with rhythm of the music/patterns. According to observation, the higher percentage of this intelligence was influenced by various activities which was held by school such as the creation of art that always be held once every two weeks. This could accommodated and develop students musical intelligence. Logical-mathematical intelligence got $13 \%$ or belong to 5 students. This acquisition quite low if compared to other multiple intelligences. This result indicates that few students who have the ability of logic and analyzing. According to the results of the interview with some teachers, the lower percentage of this intelligence caused by teacher centered 
activities. It leads to the student abilities of analyzing, logic and critical thinking become less developed. This ability can be developed through the activities which related to analyzing data, knowing of various patterns, and developing of abstract thinking.

Based on these results, we can conclude that each student has the different of intelligence, but when their intelligence could not be facilitated, it can make these intelligence could not develop optimally. In a similar vein, Hamzah [13] reveal that these intelligences are already there since they were child, but because they are not sharpened, it leads that intelligence couldn't develop optimally.

\section{B. Profile of Student's Multiple Intelligences Activity}

Integrated earth and space science learning model was designed based on 8 types of dominant intelligence belongs by students. Therefore, through this learning model it intended to be able to accommodate the students' intelligences during the implementation.

Integrated earth and space science learning model that accommodated multiple intelligences consists of various activities that can discover the dominant intelligence of students. On the other hand this model can develop other intelligences which less dominant in their self. Based on the results, it was found that the highest percentage of multiple intelligences activity were $89.85 \%$ of naturalist intelligence, $88.32 \%$ of kinesthetic intelligence, $88.11 \%$ of visual-spatial, and $87.16 \%$ of interpersonal intelligences. Meanwhile the lowest percentage of multiple intelligences activity was verballinguistic intelligence that only reach $82.74 \%$. The results was different with the research by Liliawati [14] which showed the highest percentage of multiple intelligences activity were intrapersonal, interpersonal, visual and verbal intelligence. But overall, the results have gained over $80 \%$.

Naturalistic intelligence is the highest activity which appeared during implementation of this model. Although the dominant of naturalistic intelligence only get $26 \%$ of students, through this learning this intelligence can be developed and be facilitated, proven by gaining the highest percentage. Kinesthetic and visual-spatial intelligence get $88.32 \%$ and $88.11 \%$. It made these intelligence as second of highest activities which appeared during implementation of this model. Although these intelligence is the lowest of dominant intelligence, it leads to these intelligence can be improved and developed. In addition, interpersonal intelligence is one of highest activities which appeared during learning implementation. This intelligence get $87.16 \%$, it makes sense because interpersonal counted as the highest of obtained dominant intelligence.

Logical-mathematical intelligence get $85.47 \%$ on the appearance of multiple intelligences activity. This percentage is higher than percentage gaining of its dominant intelligence which only get $13 \%$. There was the significant difference between appearance of activity and its dominant intelligence. It proves that the logical-mathematic intelligence can be developed and improved during implementation of this learning model. On the other hand musical intelligence get $84.95 \%$ on multiple intelligences activity. This percentage is higher than its dominant intelligence. Therefore, this intelligence can also develope during the implementation of this model.

Intrapersonal activity counted as the lowest of multiple intelligences activity. This intelligence only get $84.63 \%$ from all students activity during implementation of this model. Based on the results of dominant intelligence, interpersonal is highest dominant intelligence which belongs to students. According on observation, this intelligence activity is influenced by the lack of student confidence on discussion. In addition other things were caused by a lot of group activities, and it can make the students who have this intelligence become more difficult to follow the lesson activity. However with obtained percentage $84.63 \%$, this showed that interpersonal intelligence students can be developed throught implementation of this learning model. Verbal-linguistic intelligence is the lowest of the multiple intelligence activity. This intelligence is only get $82.74 \%$. It makes sense, because this intelligence is the lowest dominant intelligence belong to students. However, with gained percentage of $82.74 \%$, which higher than its dominant intelligence, it proves that this verbal-linguistic intelligence also can be developed.

\section{Correlations Between Dominant Intelligence And The Appearance of Multiple Intelligences Activity}

The success of this learning model in accommodating the multiple intelligences were based on correlation between dominant multiple intelligence and the appearance of multiple intteligences activity. Table III. showed the pattern correlation between dominant multiple intelligence and the appearance of multiple intteligences activity.

\section{TABLE III. THE RECAPITULATION OF CORRELATION BETWEEN DOMINANT INTELLIGENCE AND THE APPEARANCE OF MULTIPLE INTTELIGENCES ACTIVITY.}

\begin{tabular}{|c|c|c|c|c|c|c|c|c|}
\hline $\begin{array}{c}\text { Multiple Intelligences } \\
\text { Activity } \\
\text { Dominant } \\
\text { Multiple } \\
\text { Intelligence }\end{array}$ & & & & & & & & \\
\hline Naturalistic (\%) & 93 & 86 & 86 & 88 & 91 & 90 & 91 & 85 \\
\hline $\begin{array}{c}\text { Logical-Mathematical } \\
\text { (\%) }\end{array}$ & 90 & 98 & 89 & 87 & 90 & 98 & 91 & 93 \\
\hline Verbal-Linguistic (\%) & 95 & 93 & 99 & 97 & 92 & 96 & 95 & 95 \\
\hline Musical (\%) & 94 & 87 & 89 & 94 & 89 & 94 & 91 & 87 \\
\hline Visual-Spatial (\%) & 97 & 97 & 91 & 91 & 97 & 96 & 97 & 88 \\
\hline Kinesthetic (\%) & 87 & 85 & 79 & 81 & 91 & 95 & 85 & 88 \\
\hline Interpersonal (\%) & 93 & 88 & 88 & 88 & 89 & 90 & 92 & 84 \\
\hline Intrapersonal (\%) & 87 & 83 & 80 & 84 & 88 & 86 & 84 & 86 \\
\hline
\end{tabular}

In Table III showed the pattern between dominant multiple intelligence and the appearance of multiple intteligences activity, such as the appearance of naturalistic activity, logical, verbal-linguistic, musical, visual-spatial, and kinaesthetic intelligence that have correlation with its dominant intelligence. But there were multiple intelligence activities that have no correlation with its dominant intelligence. Those were intrapersonal and interpersonal 
intelligences. To explain the whole of pattern correlation, it was used the diagram below.

The results show that the percentage of student's dominant intelligences that have correlation with appearance of the student's multiple intelligences activity was $87 \%$. Meanwhile, percentage of student's dominant intelligence that have no correlation with appearance of student's multiple intelligences activity was $13 \%$. There were 38 students as participants in this research and dominant multiple intelligences of 33 student accommodate. The five other's was less or not being accommodated. These result is the same with Lutfiani's [15] that showed there was correlation $86 \%$ and no correlation $14 \%$ on the implementation on intergrated learning model. But, in Lutfiani's research the correlation lies on kinesthetic, visualspatial, interpersonal and logical-mathematical intteligence.

Based on the result, there were 33 students whose the intelligence were accommodated. Then five other students whose intelligences were less or not being accommodated. It proves that through the implementation of this model, most of student's multiple intelligences have been accommodated. Therefore, there were $13 \%$ student's intelligences which could not be accommodated. These intelligences were intrapersonal and interpersonal intelligence. Interpersonal intelligences which have no correlation with its dominant intelligence caused by the grouping which based on student's dominant intelligence. The student can not choose with whom they will discuss and do the task, because of that not every students can socialitation well with other member's group. According to the interview with number of students, most of students create a group to do something together include study, do the task, and hangout. Beside that, the higher value on dominant of intrapersonal intelligence was participated on caused interpersonal intelligence have no correlation with it's dominant intelligence. Students which have high the interpersonal intelligence learn by themselves. It makes the team work was not optimum. Intrapersonal intelligence have no correlation because there were too many group activities. It makes the students which have intrapersonal intelligence couldn't do group activity optimally because they tend to like to work individually.

\section{Concept Mastery}

This integrated earth and space science learning model which accommodate multiple intelligences also have an aim to improve the students mastery of concept. This student's concept mastery was obtained by calculating the $\mathrm{N}$-gain from pre-test and post-test. As the following Table IV, the student's pre-test and post-test of concept mastery recapitulation.

TABLE IV. POST-TEST AND PRE-TEST RECAPITULATION AND NGAIN

\begin{tabular}{|c|c|c|c|c|c|}
\hline & $\begin{array}{c}\text { Highest } \\
\text { Score }\end{array}$ & $\begin{array}{c}\text { Lowest } \\
\text { Score }\end{array}$ & Mean & $\begin{array}{c}\text { Max } \\
\text { Score }\end{array}$ & N-Gain \\
\hline $\begin{array}{c}\text { Pre- } \\
\text { test }\end{array}$ & 67 & 19 & 43 & & 133 \\
\cline { 1 - 3 } $\begin{array}{c}\text { Post- } \\
\text { test }\end{array}$ & 126 & 83 & 107 & $\begin{array}{c}0,72 \\
\text { (high) }\end{array}$ \\
\hline
\end{tabular}

Based on Table IV. The highest score on the pre-test is 67 and the lowest score is 19. The mean of pre-test and posttest is 43. It was lower than the highest score. The post-test result has 126 as the highest score and 83 as the lowest score. The mean of the test is 133. According to the data of pre-test and post-test, we can get the value of $N$-gain which is 0.72 . This mean that the gained value was counted as high category. This results was better than the result by Khodir [16] which get only 0.42 in gain value (interpretated as middle category) for student concept mastery.

In concept mastery about the earthquake concept, there were some concepts that support to have a mastery of the matter. The concept was design in several sub themes. The sub theme include "Lebih Dekat Dengan Gempa", Ketika Tsunami Menari", dan "Ketika Gunung Api Bernyanyi". N-gain analysis of each sub themes shows that all of the $N$-gain value is above 0.70 . This result include on high category. Student concept mastery in sub theme "Ketika Tsunami Menari" get the highest gain, it was 0.73 . The sub theme "Lebih Dekat dengan Gempa" get the lowest gain, it was 0.70. The obtained of $N$-gain was based on students' answer. Based on the results, we know that through the implementation of integrated earth and space

\section{CONCLUSION}

Integrated earth and space science learning model based on multiple intelligences can accommodate most of student's multiple intelligences and also can improve student's concept mastery in earth structure and disaster.

\section{Acknowledgment}

We would to thank to Mr Agus Fannie Chandra, M.Pd and Mr Drs. Taufik Ramlan, M.Si which have been judgement the instrument. We also would like to thank the entire teachers staff, and students of SMPN 1 Warungkiara who give the opportuny to do the research there. Thank you to Sitti Aisyah and Lisna Anggraeni for help on translate this article.

\section{References}

[1] Barstow, D. \& Geary, E. "Revolution in Earth and Space Science Education". [Online]. http://www.EarthScienceEdRevolution.org. [9 Agustus 2014], 2002.

[2] Michael O. Martin, Ina V.S. Mullis, Pierre Foy, Gabrielle M. Stanco, Foy, EugineoJ. Gonzalez, TIMSS International Results in Science. Tersedia: http://timss.bc.edu [8 Februari 2015], 2011.

[3] Gardner, H. Frames of Mind: The Theory Multiple Intelligences. New York: Basic Book, 1983.

[4] Jasmine, Julia. Mengajar Dengan Metode Kecerdasan Mejemuk. Bandung: Nuansa, 2007

[5] Amstrong, Thomas. Smart Baby's Brain. Jakarta: Prestasi Pustaka, 2003

[6] Dahar, R.W, Teori-Teori Belajar. Jakarta: Erlangga, 2003

[7] Sudjana, N dan Ibrahim, Penelitian dan Penilaian Pendidikan. Bandung: Sinar Baru Algesindo, 2011

[8] Trianto, Model Pembelajaran Terpadu. Jakarta: Bumi Aksara, 2015

[9] Forgaty, J.R. \& Stoehr, J, Integrating Curricula With Multiple Intelligences: Teams, Themes, and Threads. United State of America: A, 2007

[10] Liliawati, W. \& Herdiwijaya, D. Analisis Kebutuhan Astronomi Terintegrasi Berbasis kecerdasan Majemuk (TKM) untuk Membekalkan 
Literasi Astronomi. Prosiding Seminar Himpunan Astronomi Indonesia, 2011

[11] Winarto, Paulus.. Tes Talenta (Kecerdasan Majemuk). [Online]. Tersedia: www.pauluswinarto.com. [28 Maret 2015], 2013

[12] Hake, R R. Analizing Change/Gain Scores. [Online].

[13] http://www.physics.indina.edu/ᄀsdi/AnalyzingChange-Gain.pdf [18 November 2012], 2009

[14] Hamzah \& Kuadrat, Masri,. Mengelola Kecerdasan dalam Pembelajaran. Jakarta: Bumi Aksara, 2011

[15] Liliawati, dkk. Analisis Karakter Mahasiswa yang Terbangun Melalui Perkuliahan IPBA Terintegrasi Berbasis Kecerdasan Majemuk. Universitas Pendidikan Indonesia, 2011

[16] Luthfiani, T.A, Analisis Karakter Diri dan Kecerdasan Majemuk Siswa Sekolah Dasar pada Model Pembelajaran IPA Terpadu yang Mengakomdasi Kecerdasan Majemuk. (Skripsi). Universitas Pendidikan Indonesia. Bandung, 2015

[17] Khodir, D A. Model Pembelajaran Games Edukatif Terintegrasi yang mengakomodasi Kecerdasan Majemuk untuk Meningkatkan Penanaman Karakter dan Pemahaman Konsep Siswa. Universitas Pendidikan Indonesia. Bandung, 2015 